\title{
Acinetobacter baumannii Infections and Antibiotic Resistance in Hospitalized Patients in an Education and Research Hospital: A Six-Year Analysis
}

\section{Bir Eg̃itim ve Araștırma Hastanesinde Yatan Hastalarda Acinetobacter baumannii İnfeksiyonları ve Antibiyotik Direnci: Altı Yıllık Analiz}

Tug̃ba ARSLAN GÜLEN'(IID), Ayfer IMRE'(IiD), illker ÖDEMiș²(IiD), Üner KAYABAȘ'(IiD)

\footnotetext{
${ }^{1}$ Department of Infectious Diseases and Clinical Microbiology, Faculty of Medicine, Nig̃de Ömer Halisdemir University, Nig̃de, Turkey

${ }^{2}$ Clinic of Infectious Diseases and Clinical Microbiology, Nig̃de Training and Research Hospital, Nig̃de, Turkey
}

Cite this article as: Arslan Gülen T, imre A, Ödemiş $i$, Kayabaş Ü. Acinetobacter baumannii infections and antibiotic resistance in hospitalized patients in an education and research hospital: a six-year analysis. FLORA 2020;25(4):563-71.

\begin{abstract}
Introduction: Acinetobacter baumanii causes difficulties in the treatment of nosocomial infections due to increasing resistance worldwide. With an increase in resistant infections, the use of colistin has come to the fore. We aimed to investigate the antimicrobial resistance profile of A. baumanii strains isolated from clinical specimens as hospital-acquired colonizations and infection agents and to evaluate the clinical and microbiologic responses and adverse effects of antibiotic regimens used in patients who were isolated because of having infectious agents.
\end{abstract}

Materials and Methods: A retrospective descriptive study of 326 adult patients with nosocomial A. baumannii colonizations and infections was conducted between January 2012 and December 2017 in Niğde Education and Research Hospital. In addition, a total of 212 adult patients who received at least 72 hours of antimicrobial therapy were evaluated. Standard and automated methods were used to identify isolated strains and antibiotic susceptibility. The antimicrobial susceptibility profile change over the 6-year period was evaluated. Adverse effects, and clinical and microbiologic response were evaluated in patients receiving antimicrobial therapy. Analysis of the variables was performed using SPSS 22.0 (IBM Corporation, Armonk, New York, United States).

Results: When antimicrobial resistance rates were examined, it was seen that imipenem (99.7\%), ampicillin sulbactam (81.6\%), cefoperazone sulbactam (60.3\%), netilmicin (89.4\%), tobramycin (88.4\%), gentamicin (83.1\%), amikacin (91.6\%) and tigecycline (33.7\%) had resistance rates; colistin resistance was not detected in the isolates. Resistance rate to other antibiotic groups was $100 \%$. The resistance rates of ampicillin sulbactam, cefoperazone sulbactam, gentamicin, amikacin, and tigecycline were found to be statistically significant $(p<0.05)$. There were no significant differences in terms of nephrotoxicity, and clinical and microbiologic response among patients in whom colistin was used in combination with carbapenem, ampicillin/sulbactam, cefoperazone/sulbactam, and tigecycline $(p>0.05)$.

Conclusion: In accordance with the global data, antimicrobial resistance rate in A. baumanii isolates was found to be high in our study. Treatment regimens in which colistin is used with other antimicrobial agents have no superiority in terms of efficacy and adverse effects. There is a clear need for new and effective antimicrobial agents in the treatment of resistant A. baumanii infections.

Key Words: Acinetobacter baumanii; Antimicrobial resistance; Colistin; Combination therapy; Adverse effect; Antimicrobial response

Received/Geliș Tarihi: 08/10/2019 - Accepted/Kabul Ediliș Tarihi: 15/03/2020

${ }^{\circledR}$ Copyright 2020 by Flora. Available on-line at www.floradergisi.org. 


\title{
ÖZ \\ Bir Eg̃itim ve Araștırma Hastanesinde Yatan Hastalarda Acinetobacter baumannii İnfeksiyonları ve Antibiyotik Direnci: Altı Yılık Analiz
}

\author{
Tug̃ba ARSLAN GÜLEN', Ayfer iMRE'1, ilker ÖDEMiș², Üner KAYABAȘ'
}

${ }^{1}$ Nig̃de Ömer Halisdemir Üniversitesi, Tıp Fakültesi, İnfeksiyon Hastalıkları ve Klinik Mikrobiyoloji Anabilim Dalı, Nig̃de, Türkiye

${ }^{2}$ Nig̃de Eg̃itim ve Araștırma Hastanesi, İnfeksiyon Hastalıkları ve Klinik Mikrobiyoloji Klinig̃i, Nig̃de, Türkiye

Giriş: Acinetobacter baumannii, dünya genelinde artan direnç ile beraber, tedavisi zor nozokomiyal infeksiyonlara neden olmaktadır. Dirençli infeksiyonlardaki artışla birlikte, kolistin kullanımı tekrar ön plana çıkmışır. Bu çalışma ile, hastane kaynaklı kolonizasyon ve infeksiyon etkeni olarak klinik örneklerden izole edilen A. baumannii suşlarının antimikrobiyal direnç profilini araştırmayı ve infeksiyon etkeni olarak izole edilen hastalarda kullanılan kolistin temelli antibiyotik rejimlerinin klinik ve mikrobiyolojik yanıt ve yan etkilerini değerlendirmeyi amaçladık.

Materyal ve Metod: Tanımlayıcı, retrospektif bir çalışma olup, Ocak 2012-Aralık 2017 tarihleri arasında Niğde Eğitim Araştırma Hastanesi'nde yatarak izlenen ve çeşitli kültürlerinde dirençli A. baumannii üremesi olan 326 erişkin hasta ile A. baumannii'nin hastane infeksiyonu etkeni olarak saptandığı ve en az 72 saat antimikrobiyal tedavi almış 212 erişkin hasta çalısmaya dahil edildi. Antimikrobiyal duyarlıık profilinin 6 yıl içindeki yıllara göre değişimi değerlendirildi. i̇zole edilen suşların tanımlanmasında ve antibiyotik duyarılıklarının saptanmasında standart ve otomatize yöntemler kullanıldı. Antimikrobiyal tedavi verilen hastalarda yan etkiler, klinik yanıt ve mikrobiyolojik yanıt değerlendirildi. Değişkenlerin analizinde SPSS 22.0 (IBM Corparation, Armonk, New York, United States) programı kullanıldı.

Bulgular: Antimikrobiyal direnç oranları incelendiğinde, imipenem \%99.7, ampisilin sulbaktam \%81.6, sefoperazon sulbaktam\%60.3, netilmisin \%89.4, tobramisin \%88.4, gentamisin \%83.1, amikasin \%91.6 ve tigesiklin direncinin \%33.7 oranında olduğu görülürken, izolatlarda kolistin direnci tespit edilmedi. Diğer antibiyotik gruplarına karşı direnç oranı \%100 idi. Altı yıl içinde değişen direnç oranları incelendiğinde, ampisilin sulbaktam, sefoperazon sulbaktam, gentamisin, amikasin ve tigesiklin dirençlerindeki değişikliğin istatistiksel olarak anlamlı olduğu saptandı ( $p<0.05$ ). Kolistinin karbapenem (imipenem (IMP)/meropenem(MEN)), ampisilin/sulbaktam, sefoperazon/sulbaktam ve tigesiklin ile beraber kullanıldığı hastalar arasında nefrotoksisite, klinik ve mikrobiyolojik yanıt açısından anlamlı fark saptanmadı ( $p>0.05)$.

Sonuç: Global verilerle uyumlu olarak, çalışmamızda A. baumannii izolatlarında antimikrobiyal direncin yüksek olduğu görülmektedir. Kolistinin diğer antimikrobiyal ajanlarla beraber kullanıldı̆̆ tedavi rejimlerinin etkinlik ve yan etki açısından birbirlerine üstünlüğünün bulunmadığı saptanmıştır. Dirençli A. baumannii infeksiyonlarının tedavisinde yeni ve etkili antimikrobiyal ajanlara ihtiyaç olduğu nettir.

Anahtar Kelimeler: Acinetobacter baumannii; Antimikrobiyal direnç; Kolistin; Kombinasyon tedavisi; Antimikrobiyal yanıt

\section{INTRODUCTION}

Acinetobacter baumanii is one of the most important microorganisms in infection control because of frequent hospital-acquired infections and increased antimicrobial resistance. As a result, length of hospital stay, morbidity, mortality, and hospitalization costs are increasing ${ }^{[1,2]}$. Carbapenem resistance in particular has shown a great increase in recent years. According to the European Antimicrobial Resistance Surveillance Network (EARS-Net) 2016 data, it appears that the carbapenem resistance in European isolates is $>50 \%[3]$. It is possible to examine the antimicrobial resistance of $A$. baumanii in three different categories. Multidrug resistance (MDR) is defined as resistance to at least one antimicrobial agent in three or more categories, extensive drug resistance (XDR) is defined as resistance to all antimicrobial agents except two antibiotic categories. Pandrug resistance (PDR) is the development of resistance to all antimicrobial agents ${ }^{[4]}$.

An old drug, colistin, a cationic polypeptide antibiotic that belongs to the polymyxin group, has resurfaced because of the lack of new antimicrobial agents that are effective in the treatment of carbapenem-resistant gram-negative bacterial infections. In clinical practice, colistin is used alone or with other antimicrobial agents. It 
seems that the treatment options are not superior to each other in the literature ${ }^{[5-7]}$. Colistin is not an innocent drug because of its side effects. It is an agent that should be considered during its use especially due to its nephrotoxic side effect.

The aim of this study was to investigate the antimicrobial resistance patterns of $A$. baumanii isolates obtained from various clinical specimens and to evaluate the clinical and microbiologic responses and adverse effects of antimicrobial agents, especially colistin based therapies, used in patients isolated as infection agents.

\section{MATERIALS AND METHODS}

\section{Study Design}

This retrospective, observational study included 326 adult patients (aged 18 years and older) who were hospitalized in an education and research hospital between January $1^{\text {st }}, 2012$, and December $31^{\text {st }}, 2017$. Patients who had A. baumanii isolation in various clinical samples after the 48th hour of hospitalization were included in the study. Antimicrobial resistance rates of these isolates have been examined over the years. The clinical and microbiologic responses and adverse effects of the antimicrobial agents used were evaluated in 212 adult patients who were treated for at least 72 hours. Daily visits of intensive care units are carried out by infectious diseases specialist and infection control nurses in our hospital. The clinical and laboratory findings and culture results of the patients are monitored and their treatments are arranged in accordance with rational antibiotic applications. The demographic characteristics, and clinical and laboratory findings of the patients were obtained by retrospectively screening surveillance records of the infection control committee and the patients' files. The first isolates of the patients with multiple $A$. baumannii isolation and infection were included in the study.

\section{Definitions}

Infection diagnoses were made according to the criteria defined by the Centers for Disease Control and Prevention $(\mathrm{CDC})^{[8]}$. Clinical response was defined as resolution of infection sign/ symptoms and laboratory findings at the end of the antibiotic therapy in the patients who completed the treatment. No bacterial growth from site-specific follow-up cultures taken after 72 hours of therapy was defined as microbiologic response ${ }^{[5]}$. Nephrotoxicity was defined as a serum creatinine concentration of $\geq 2 \mathrm{mg} / \mathrm{dL}$ or a decrease in basal creatinine clearance of $50 \%$ or more in patients with serum basal creatinine < $1.2 \mathrm{mg} / \mathrm{dL}$. In patients with a serum creatinine value of $\geq 1.2 \mathrm{mg} / \mathrm{dL}$, a $50 \%$ or greater increase in serum creatinine level or a $50 \%$ reduction in basal serum creatinine clearance or the necessity of renal replacement therapy were evaluated as nephrotoxicity ${ }^{[9]}$

\section{Identification of Microorganisms and Antimicrobial Susceptibility}

Conventional methods and a VITEK 2.0 (BioMerieux, France) were used for the identification of isolated strains and Kirby-Bauer disc diffusion and the VITEK 2.0 (bioMerieux, France) were used for antibiotic susceptibility testing. Susceptibilities of amikacin, gentamycin, tobramycin, netilmicin, ampicillin sulbactam, piperacillin, piperacillin tazobactam, ceftriaxone, ceftazidime, cefotaxime, cefepime, imipenem, meropenem, aztreonam, ciprofloxacin, tetracycline, co-trimoxazole, tigecycline, and colistin were studied in the strains. Sensitivity of the antimicrobials was tested and interpreted according to the recommendations of the European Committee on Antimicrobial Susceptibility Testing (EUCAST) and the Clinical and Laboratory Standards Institute (CLSI) ${ }^{[10,11]}$. Not all antibiotics were studied in all strains because the antibiotic susceptibility of isolates was studied on different cards of the VITEK 2 automated system. The strains resistant to $\geq 1$ antimicrobial agent in $\geq 3$ categories were accepted as MDR, and strains resistant to all antimicrobial agents except two antibiotic categories were classified as $\mathrm{XDR}^{[4]}$.

\section{Ethics Approval}

Ethics committee approval was received from Niğde Ömer Halisdemir University Ethics Committee (2018/11-04).

\section{Statistical Analysis}

The SPSS 22.0 program (IBM Corporation, Armonk, New York, USA) was used to analyze the variables. The Shapiro-Wilk test was used to 
assess the normal distribution of the data. The homogeneity of variance was evaluated using the Levene test. The independent-samples t-test was used in conjunction with the Bootstrap results for the comparison of two independent groups according to the quantitative data, and the Mann-Whitney $\mathrm{U}$ test was used with the Monte Carlo results. Pearson's Chi-square test was used with Monte Carlo simulation, and Fisher's backward logistic regression was used to determine the cause-effect relationship of the categorical response variable in categories with explanatory variables. Quantitative variables are shown as mean \pm standard deviation $(\mathrm{SD})$ and median range (maximum-minimum), and categorical variables as $\mathrm{n}(\%)$. The variables were examined at 95\% confidence intervals, and $\mathrm{p}$ values less than 0.05 were accepted as significant.

\section{RESULTS}

A. baumanii was determined in 55 samples in 2012, 41 in 2013, 63 in 2014, 40 in 2015, 71 in 2016, and in 56 clinical samples in 2017. The isolates were collected from respiratory (58.6\%), blood (26.4\%), wound (11.9\%), and urine samples (3.1\%). Some 87.7\% (186/212) of the patients were followed in intensive care units (ICUs) and 12.3\% (26/212) were followed in other wards. The most common comorbid disease was chronic obstructive pulmonary disease (COPD). Demographic characteristics of the patients are given in Table 1 . Overall rates of resistance were as follows: imipenem $=99.7 \%$, ampicillin sulbactam $=81.6 \%$, cefoperazone sulbactam $=60.3 \%$, netilmicin $=89.4 \%$, tobramycin $=88.4 \%$, gentamicin $=83.1 \%$, amikacin $=91.6 \%$, and tigecycline $=33.7 \%$. No colistin resistance was detected in the isolates. When resistance rates were evaluated over the 6-year period, alterations of ampicillin sulbactam, cefo-

Table 1. Demographic and clinic characteristics of the patients with nosocomial infections caused by Acinetobacter baumannii

\begin{tabular}{|c|c|}
\hline Variables & \\
\hline Age, (median, min-max) & $68(18-98)$ \\
\hline $\begin{array}{c}\text { Sex, } \mathrm{n}(\%) \\
\text { Female } \\
\text { Male }\end{array}$ & $\begin{array}{l}67(31.6) \\
145(68.4)\end{array}$ \\
\hline Duration of hospitalization before infection (median, min-max) & $17(3-129)$ \\
\hline $\begin{array}{l}\text { Clinic, n (\%) } \\
\text { Intensive care unit } \\
\text { Surgical units } \\
\text { Internal medicine units }\end{array}$ & $\begin{array}{l}186(87.7) \\
21(9.9) \\
5(2.4)\end{array}$ \\
\hline $\begin{array}{l}\text { Comorbid diseases, } \mathrm{n}(\%) \\
\text { Chronic obstructive pulmonary disease } \\
\text { Diabetes mellitus } \\
\text { Heart failure } \\
\text { Coronary artery disease } \\
\text { Chronic renal failure } \\
\text { Immunosuppression } \\
\text { Malignancy }\end{array}$ & $\begin{array}{l}94(44.3) \\
57(26.9) \\
54(25.5) \\
27(12.7) \\
24(11.3) \\
20(9.4) \\
4(1.9)\end{array}$ \\
\hline $\begin{array}{l}\text { Antimicrobials used in treatment, n (\%) } \\
\text { Cefoperazone/sulbactam } \\
\text { Colistin + Carbapenem (Imipenem/Meropenem) } \\
\text { Tigecycline } \\
\text { Colistin + Ampicillin/sulbactam } \\
\text { Colistin + Cefoperazone/sulbactam } \\
\text { Colistin + Tigecycline } \\
\text { Ampicillin/sulbactam } \\
\text { Colistin }\end{array}$ & $\begin{array}{l}48(22.6) \\
45(21.2) \\
44(20.8) \\
39(18.4) \\
12(5.7) \\
11(5.2) \\
11(5.2) \\
2(0.9)\end{array}$ \\
\hline
\end{tabular}


perazone sulbactam, gentamicin, amikacin, and tigecycline resistance were found to be statistically significant $(\mathrm{p}<0.05)$ (Table 2). Of the 326 strains, 141 (43.3\%) were MDR and 185 (56.7\%) were XDR. No PDR isolates was detected. The rate of MDR in the strains decreased significantly and XDR ratio increased from 2012 to 2017 ( $p<0.05)$ (Table 3). The most effective antimicrobial agents were colistin, tigecycline, and cefoperazone sulbactam. In 322 patients with antibiotic use within 30 days prior to $A$. baumanii isolation, piperacillin tazobactam, third-generation cephalosporin and carbapenem (imipenem/meropenem) were the most commonly used antibiotics (Table 3). The antibiotics used in the treatment of 212 patients identified as having infectious agents are shown in Table 4. When colistin-containing treatment regimens were examined for clinical response, microbiologic response, adverse effects and nephrotoxicity, no significant difference was found between imipenem/meropenem-colistin, ampicillin sulbactam-colistin, cefoperazone sulbactam-colistin, and tigecycline-colistin combinations ( $p>0.05$ ) (Figure 1). Fifty-four (27.9\%) patients had adverse effects related to the antimicrobials, and 52 (43.7\%) patients who received colistin-based treatment had nephrotoxicity. In 4 (8.3\%) patients treated with cefoperazone sulbactam, an increase in international normalized ratio (INR) was detected, yet these patients had no additional medical treatment to cause an increase in INR value. Hepatotoxicity was observed in one (1.8\%) patient who received tigecycline therapy; however, no simultaneous hepatotoxic drug had been used for this patient.

\section{DISCUSSION}

Due to the increased resistance to antimicrobial agents, nosocomial infections caused by MDR isolates as well as Acinetobacter species with XDR and PDR resistance profiles threaten public health worldwide $e^{[3,12,13]}$. In our study, it was observed that drug resistance was high in the strains isolated in our hospital. In a recent study, a 5-year analysis of 914 hospital-acquired Acinetobacter isolates has been performed, and $4.9 \%$ of the strains has been found susceptible to all tested antibiotics, and $92.89 \%$ has been found to be MDR. In the same study, the colistin-re-

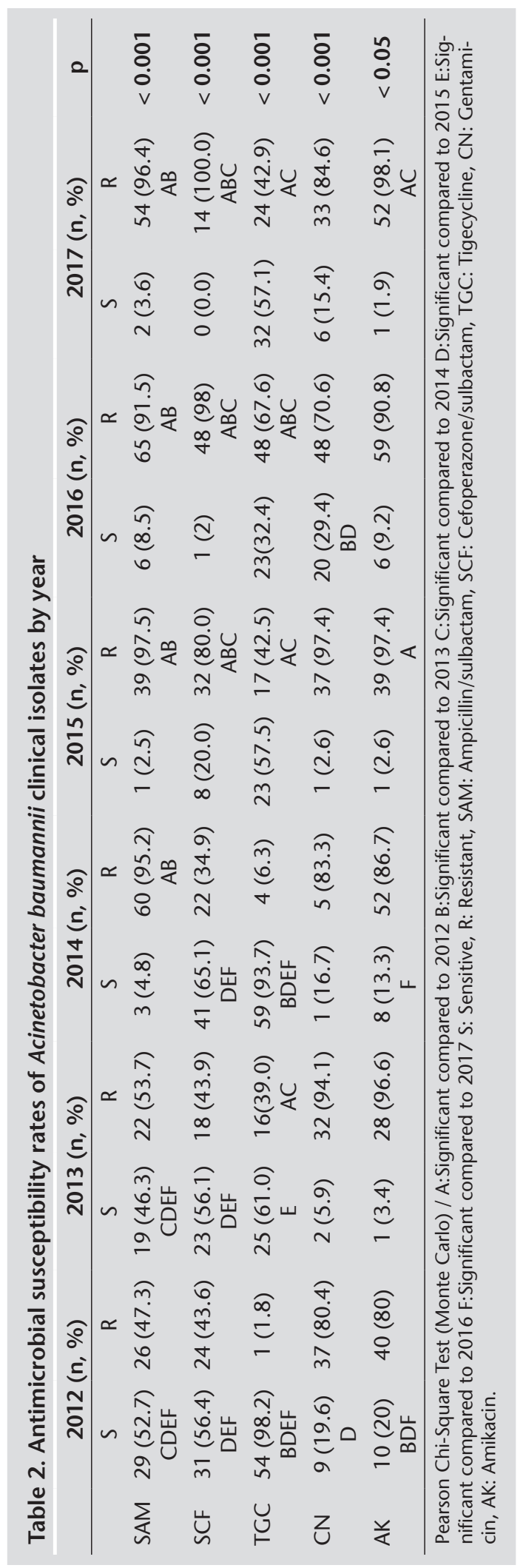


Acinetobacter baumannii Infections and Antibiotic Resistance in Hospitalized Patients in an

Education and Research Hospital: A Six-Year Analysis

Table 3. MDR and XDR ratios in Acinetobacter baumannii isolates between 2012-2017

\begin{tabular}{lccccccc} 
& $\mathbf{2 0 1 2}$ & $\mathbf{2 0 1 3}$ & $\mathbf{2 0 1 4}$ & $\mathbf{2 0 1 5}$ & $\mathbf{2 0 1 6}$ & $\mathbf{2 0 1 7}$ & $\mathbf{p}$ \\
\hline MDR n (\%) & $38(69.1)$ & $22(53.7)$ & $47(74.6)$ & $10(25)$ & $16(22.5)$ & $8(14.3)$ & $<0.05$ \\
XDR n (\%) & $17(30.9)$ & $19(46.3)$ & $16(25.4)$ & $30(75)$ & $55(77.5)$ & $48(85.7)$ & $<0.05$ \\
\hline \multicolumn{7}{l}{ Pearson Chi-Square Test / MDR:Multi-drug resistance XDR:Extreme-drug resistance } \\
\end{tabular}

Table 4. Antimicrobials used before the isolation of Acinetobacter baumannii, n (\%)

$\begin{array}{ll}\text { Piperacillin/tazobactam } & 93(28.9) \\ 3^{\text {rd }} \text { generation cephalosporin } & 85(264) \\ \text { Carbapenem } & 80(24.8) \\ \text { Quinolone } & 21(6.5) \\ 1^{\text {st }} \text { generation cephalosporin } & 17(5.3) \\ \text { Glycopeptide } & 16(5.0) \\ \text { Ampicillin/sulbactam } & 8(2.5) \\ \text { Metronidazole } & 2(0.6)\end{array}$

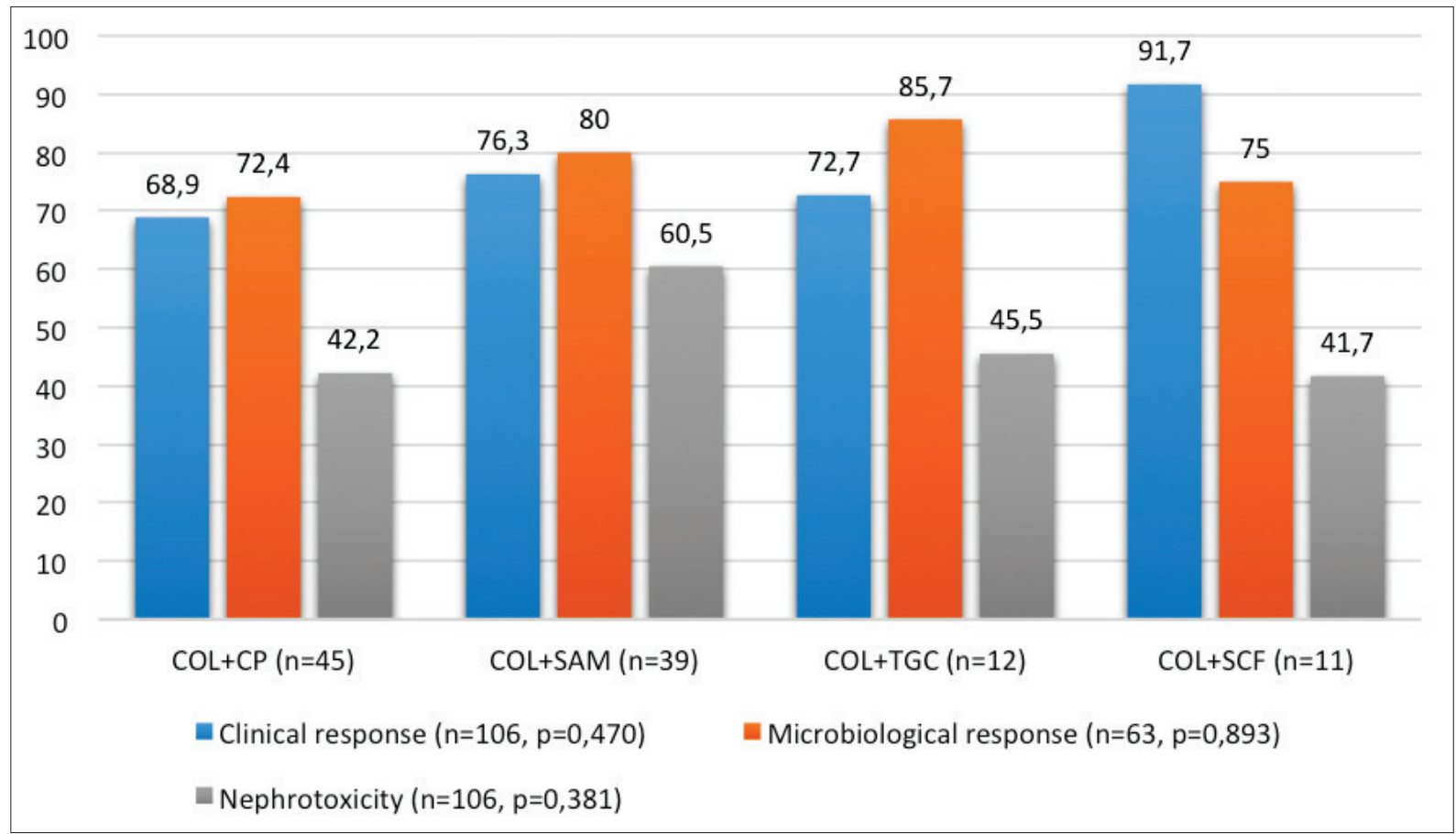

Figure 1. Evaluation of colistin combination therapy in terms of nephrotoxicity, clinical and microbiological response.

COL: Colistin, CP: Carbapenem (Imipenem/Meropenem), SAM: Ampicillin/sulbactam, TGC: Tigecycline, SCF: Cefoperazone/ sulbactam.

sistant isolate rate was $2.95 \%$, whereas colistin resistance was not detected in any strains in our study. In that study, in the evaluation of antimicrobial resistance rates according to years, significant differences were observed in carbapenem, amikacin, tobramycin, tigecycline, TMP-SMX, and colistin sensitivity ${ }^{[14]}$. Bshabshe et al. have examined the resistance profile of MDR Acinetobacter isolates found within one year and reported high resistance rates to other antimicrobials, whereas 
colistin resistance was detected in any isolates ${ }^{[15]}$. According to the Study for Monitoring using Antimicrobial Resistance Trends (SMART) data, evaluating regional resistance differences of 1011 Acinetobacter isolates obtained from intraabdominal and urinary system samples, MDR rates have been found to be high, especially in Europe and the Middle East (93\%) and low in North America $(47 \%)^{[16]}$. All of the isolates were resistant in our study and showed a correlation with regional resistance rates in this study. When clinical studies that used colistin as a monotherapy and combination therapy with other antimicrobials in resistant Acinetobacter infections are examined, the majority show that the treatment options are not superior to each other ${ }^{[6,17-19]}$. Batirel et al. have investigated the use of colistin-carbapenem, colistin-sulbactam, and colistin with other antimicrobial agents in bloodstream infections caused by XDR $A$. baumannii in their multi-center studies, which included data from 27 hospitals. No significant difference was found between combination therapies in terms of clinical and microbiologic response in this clinical trial ${ }^{[6]}$. In another study that included a total of 180 isolates including MDR and XDR A. baumannii, Pseudomonas aeruginosa, Klebsiella pneumonia, and Escherichia coli, colistin monotherapy, colistin-containing dual and triple combination therapies were not statistically different in terms of clinical and microbiologic cure rates ${ }^{[17]}$. In another study, the results of treatment of colistin-carbapenem, colistin-tigecycline, and colistin-sulbactam combinations of 236 patients with XDR $A$. baumannii respiratory tract infections have been evaluated, and it has been seen that there were no differences between the treatment options ${ }^{[18]}$. Y1lmaz et al. have also found that there were no significant differences between the clinical and microbiologic response rates of carbapenem- colistin and sulbactam-colistin treatment in 70 patients with MDR and XDR $A$. baumannii as a ventilator-associated pneumonia agent ${ }^{[19]}$. In another study including 134 patients, colistin-ampicillin sulbactam treatment has been shown to provide higher microbiologic eradication compared with treatments in which colistin was combined with carbapenem, tigecycline, and cefoperazone sulbactam, but there was no difference in terms of clinical cure ${ }^{[20]}$.
In a meta-analysis that compiled the comparative efficacy of treatments used in MDR and XDR A. baumanii infections, none of the treatment options were superior to each other in terms of clinical improvement, and colistin-containing combination therapies provided higher rates of microbiologic eradication than colistin monotherapy ${ }^{[21]}$. In our study, in accordance with the majority of the literature, clinical and microbiologic cure rates were similar in colistin combination therapies. Factors such as age, underlying diseases, use of broad-spectrum antimicrobials, clinical follow-up, and primary diagnoses are thought to affect treatment response.

The major adverse effect of restricting the use of colistin is nephrotoxicity. The incidence range is reported to be as wide as $11 \%$ and $76 \%{ }^{[22]}$. Köksal et al. have demonstrated that nephrotoxicity developed in 38 (28.6\%) of 133 patients receiving colistin treatment ${ }^{[23]}$. In another study, the rate of nephrotoxicity has been found as $46.1 \%[24]$. There are studies in the literature that used colistin with different antimicrobial agents, and there was no statistically significant difference in terms of renal toxicity between treatment combinations in these studies ${ }^{[6,19,21,24]}$. In a meta-analysis that evaluated 15 studies and 1342 patients, there were no significant differences in clinical outcomes in patients who used colistin with tigecycline, sulbactam, and other antimicrobials $^{[21]}$. In a multi-center, retrospective cohort study, the rates of nephrotoxicity have been found to be similar in the patient groups in which colistin was used with various antibacterials ${ }^{[24]}$.

Our results showed that antimicrobial resistance among Acinetobacter strains is increasing, and MDR domination is replaced by XDR. As a result of this lack of new agents available for use in treatment, it is an undeniable fact that colistin is the most appropriate treatment in many cases. The use of colistin with other antibiotics is the most preferred treatment modality for us; no associated regimens have superiority in terms of renal toxicity, and clinical and microbiological response. In order to prevent antimicrobial resistance, rational antibiotic use policies should be developed and monitored to the maximum extent possible; effective surveillance and full compliance 
with infection control measures should be ensured.

One of the limitations of our study is that not every antibiotic was studied in each strain. It was not possible to evaluate whether there was colonization in patients who had microbiologic cure because of the retrospective nature of the study. Colistin monotherapy could not be compared with colistin-containing combined therapies and other non-colistin treatments because the number of the patients treated with colistin alone was not sufficient.

\section{CONCLUSION}

In our study, antibiotic resistance in $A$. baumanii isolates was found to be high in accordance with the results of other studies. Treatment regimens in which colistin is used with other antimicrobial agents have no superiority in terms of clinical response, microbiological response and nephrotoxicity.

\section{ETHICS COMMITTEE APPROVAL}

The approval for this study was obtained from Niğde Ömer Halisdemir University Ethics Committe (Decision no: 2018/11-04, Date: 11.04.2018).

\section{CONFLICT of INTEREST}

The authors declare that they have no conflict of interest.

\section{AUTHORSHIP CONTRIBUTIONS}

Concept and Design: TAG

Data Collection or Processing: TAG, AI

Analysis/ Interpretation: TAG, IÖ

Literature Search: TAG

Writing: TAG, ÜK

Final Approval: TAG, ÜK, Aİ, İÖ

\section{REFERENCES}

1. Xie R, Zhang XD, Zhao Q, Peng B, Zheng J. Analysis of global prevalence of antibiotic resistance in Acinetobacter baumannii infections disclosed a faster increase in OECD countries. Emerg Microbes Infect 2018;7(1):31.

2. Gulen TA, Guner R, Celikbilek N, Keske S, Tasyaran M. Clinical importance and cost of bacteremia caused by nosocomial multi drug resistant Acinetobacter baumannii. Int I Infect Dis 2015;38:32-5.
3. Surveillance of antimicrobial resistance in Europe. Annual report of the European Antimicrobial Resistance Surveillance Network (EARS-Net) 2016. Available from: https://ecdc. europa.eu/sites/portal/files/documents/AMR-surveillance-Europe-2016.pdf

4. Manchanda V, Sanchaita S, Singh NP. Multidrug resistant Acinetobacter. J Glob Infect Dis 2010;2(3):291-304.

5. Kalin G, Alp E, Akin A, Coskun R, Doganay M. Comparison of colistin and colistin/sulbactam for thetreatment of multidrug resistant Acinetobacter baumannii ventilator-associated pneumonia. Infection 2014;42:37-4.

6. Batirel A, Balkan II, Karabay O, Agalar C, Akalin S, Alici $O$, et al. Comparison of colistin-carbapenem, colistin-sulbactam, and colistin plus other antibacterial agents for the treatment of extremely drug-resistant Acinetobacter baumannii bloodstream infections. Eur I Clin Microbiol Infect Dis 2014;33(8):1311-22.

7. Liang CA, Lin YC, Lu PL, Chen HC, Chang HL, Sheu CC. Antibiotic strategies and clinical outcomes in critically ill patients with pneumonia caused by carbapenem-resistant Acinetobacter baumannii. Clin Microbiol Infect 2018;24(8):908.

8. Horan T, Andrus M, Dudeck M. CDC/NHSN surveillance definition of health care associated infection and criteria for specific types of infections in the acute care setting. Am J Infect Control 2008;36:309-32.

9. Paul M, Bishara J, Levcovich A, Chowers M, Goldberg E, Singer $P$, et al. Effectiveness and safety of colistin: prospective comparative cohort study. I Antimicrob Chemother 2010;65:1019-27.

10. European Committee on Antimicrobial Susceptibility Testing (EUCAST) 2012. Breakpoint tables for interpretation of MICs and zone diameters. Version 2.0, Accessed date: January 1 2012. Available from: http://www.eucast.org/ clinical_breakpoints/.

11. Clinical and Laboratory Standards Institute. Performance Standards for Antimicrobial Susceptibility Testing. Twentieth Informational Supplement. CLSI Document M100-S21. Wayne, PA: CLSI, 2011.

12. Asif $M$, Alvi IA, Rehman SU. Insight into Acinetobacter baumannii: pathogenesis, global resistance, mechanisms of resistance, treatment options, and alternative modalities. Infect Drug Resist 2018;11:1249-60.

13. Almasaudi SB. Acinetobacter spp as nosocomial pathogens: epidemiology and resistance features. Saudi J Biol Sci 2018;25(3):586-96.

14. Maraki S, Mantadakis E, Mavromanolaki EV, Kofteridis DP, Samonis G. A 5-Year surveillance study on antimicrobial resistance of Acinetobacter baumannii clinical isolates from a tertiary Greek hospital. Infect Chemother 2016;48(3):1908.

15. Bshabshe AA, Joseph MRP, Hussein AA, Haimour W, Hamid ME. Multidrug resistance Acinetobacter species at the intensive care unit, Aseer Central Hospital, Saudi Arabia: A one year analysis. Asian Pac J Trop Med 2016;9(9):903-8. 
16. Lob SH, Hoban DJ, Sahm DF, Badal RE. Regional differences and trends in antimicrobial susceptibility of Acinetobacter baumannii. Int J Antimicrob Agents 2016;47(4):317-23.

17. Çetin ÇB, Özer Türk $D$, Şenol Ş, Dinç Horasan G, Tünger Ö. Colistin efficacy in the treatment of multidrug-resistant and extremely drug-resistant gram-negative bacterial infections. Turk J Med Sci 2016;46(5):1379-84.

18. Khawcharoenporn T, Pruetpongpun N, Tiamsak P, Rutchanawech S, Mundy LM, Apisarnthanarak A. Colistin-based treatment for extensively drug-resistant Acinetobacter baumannii pneumonia. Int I Antimicrob Agents 2014;43(4):378-82.

19. Yilmaz GR, Guven T, Guner R, Kocak Tufan Z, Izdes S, Tasyaran $M A$, et al. Colistin alone or combined with sulbactam or carbapenem against $A$. baumannii in ventilator-associated pneumonia. J Infect Dev Ctries 2015;9(5):476-85.

20. Kara I, Yildirim F, Bilaloglu B, Karamanlioglu D, Kayacan E, Dizbay $M$, et al. Comparison of the efficacy of colistin monotherapy and colistin combination therapies in the treatment of nosocomial pneumonia and ventilator-associated pneumonia caused by Acinetobacter baumannii. S Afr J Crit Care 2015;31(2):51-8.

21. Kengkla K, Kongpakwattana K, Saokaew S, Apisarnthana$\operatorname{rak} A$, Chaiyakunapruk N. Comparative efficacy and safety of treatment options for MDR and XDR Acinetobacter baumannii infections: a systematic review and network meta-analysis. J Antimicrob Chemother 2018;73(1):22-32.
22. Hassan MM, Gaifer Z, Al-Zakwani IS. Incidence and risk factors of nephrotoxicity in patients on colistimethate sodium. Int J Clin Pharm 2018;40(2):444-9.

23. Koksal I, Kaya S, Gencalioglu E, Yilmaz G. Evaluation of risk factors for intravenous colistin use-related nephrotoxicity. Oman Med J 2016;31(4):318-21.

24. Balkan II, Dogan M, Durdu B, Batirel A, Hakyemez IN, Cetin $B$, et al. Colistin nephrotoxicity increases with age. Scand I Infect Dis 2014;46(10):678-85.

\section{Address for Correspondence/Yazıșma Adresi}

\section{Dr. Öğr. Üyesi Tuğba ARSLAN GÜLEN}

Niğde Ömer Halisdemir Üniversitesi Tıp Fakültesi, İnfeksiyon Hastalıkları ve

Klinik Mikrobiyoloji Anabilim Dalı, Niğde-Türkiye

E-mail: tarslan81@yahoo.com.tr 